\title{
Cast Composite Solid Propellants with Different Combustion Stabilizers
}

\author{
Vesna Rodić ${ }^{1)}$ \\ Mirjana Dimić ${ }^{1)}$ \\ Saša Brzić ${ }^{1)}$ \\ Nikola Gligorijević ${ }^{1)}$
}

\begin{abstract}
The effect of four different compounds as the combustion stabilizers of composite solid propellants based on the AP/HTPB/IPDI has been presented in this paper. Except that, various total solid content, ammonium-perchlorate bimodal and trimodal combination of particle sizes ratio have been made by preparing the eleven formulations. For all of them, the burning rate law's parameters and temperature sensitivity, uniaxial mechanical characteristics, apparent viscosity of uncured propellants and physico-chemical and energetic values have been determined and compared.
\end{abstract}

Key words: composite solid propellant, composite rocket propellant, cast propellant, combustion stability, stabilizers, aluminium, zirconium carbide, titanium oxide, antimony oxide, temperature sensitivity, burning rate.

\section{Introduction}

C COMBUSTION of solid propellants involves a combination of the various ingredients that are consisted in the cast composite solid propellants (CSP). These ingredients decompose, evaporate and/or pyrolyze, relieving off gases, which then react, resulting in energetic flames that drive the combustion process of the propellant. The instability during the combustion has to be avoided because of many undesirable consequences and can be prevented by adding specific additives [1]. These compounds may have an influence on parameters of all characteristics, especially the ballistic performance and achieving the necessary requirements for the propellant.

The propellant sensitivity to pressure and temperature must be taken into account as well as the influence of the solid component packing (in particular the ratio of different oxidizer fractions) and casting properties. In observed compositions in this paper, ammonium perchlorate (AP) is used as a basic component, whose particle size distribution and fraction ratio significantly affect the way of combustion [2]. For this purpose, all propellant characteristics are necessary to fullfil.

The research results of the CSP including different stabilizer additives will be presented in this paper:

- aluminium, Al

- zirconium carbide, $\mathrm{ZrC}$

- titanium (IV) oxide, $\mathrm{TiO}_{2}$ and

- antimony (III) oxide, $\mathrm{Sb}_{2} \mathrm{O}_{3}$.

Their influence on the apparent viscosity change of uncured propellant during time, uniaxial mechanical characteristics, physico-chemical and energetic values, burning rate law parameters and calculated temperature sensitivity values of compositions with three different particle size distributions will be tested.

\section{Theoretical part}

Ammonium perchlorate is the most widely used crystalline oxidiser in the CSP. It has good characteristics such as good compatibility with other propellant ingredients, good performance, uniformity and availability. Performance can be attributed to the fact that, unlike oxidizers such as potassium nitrate, it is completely convertible to gaseous reaction products $[3,4]$.

Due to its unique characteristic of self-supporting deflagration, the AP combustion has been studied primarily in order to understand the combustion phenomena in the APbased CSP [5]. It happens that the exothermic decomposition of the AP takes place before melting at temperatures above $200^{\circ} \mathrm{C}\left(270-300^{\circ} \mathrm{C}\right)$. As a basic component, with the largest content, AP significantly affects the way of combustion in these formulations due to specific particle size distribution and fraction ratio.

The burning behavior and flame structure of an AP/HTPB propellant system are influenced by many factors: the chamber pressure, local velocity, AP particle size and mass fraction [3]. The appearance of irregular combustion may occur at a specific particle size distribution of oxidizer powder (the packing density and unfilled space between) and $\mathrm{AP} / \mathrm{binder}$ ratio. In order to achieve certain requirements and provide good properties, it is necessary to define different combinations of AP particle size distribution of various fractions, total AP and total solid phases content. When the particle size ratio (coarse/fine) is increased up to a level of significant interspace, the burning of fine AP particles will be inhibited by the melting layer of the binder. For the particle size of $20 \mu \mathrm{m}$, it may be assumed that the AP and HTPB are thermally isolated in the condensed phase. If an energy transfer is allowed between the two segments, the surface

\footnotetext{
1) Military Technical Institute (VTI), Ratka Resanovića 1, 11132 Belgrade, SERBIA

Correspondence to: Vesna Rodić; e-mail: springvesna63@gmail.com
} 
temperature of the AP will be reduced, leading to a decrease in the overall burning rate [3]. If there are some compounds taking over the energy transfer to themselves, because of the higher melting points, it is possible to change the combustion process during the form of laminar flow.

The normal burning of CSP produces a burn rate/pressure curve including relatively constant positive slope over the range of expected operating pressures.

The regime thrust, ideally, should be met in all operating conditions, especially in the application temperature range. However, the ballistic properties of propellants show a significant dependence on the external temperature, which affects the operation in a given range.

The combustion of CSP consist of the series of processes. The energetic characteristics and performing rate of these processes determine the propellant burning rate, surface temperature, flame hight and burning surface appearance.

In order to produce a usable propellant formulation, it is necessary to control the burn rate of the propellant, to prevent unacceptable performance (too high or too low pressure) for the intended purpose of the device. The value of temperature sensitivity of the propellant is very important for defining and predicting the ballistic performance and it is expressed as the percent change in burning rate per degree change in the propellant temperature. The first requirement is to obtain a set of burning rate data at various initial temperatures and pressures [6].

Initial propellant temperature is an important factor of the burning rate level and working regime of the rocket motor, but this influence is unchangeable during motor operation. It is best to take into account the burning rate dependence of the pressure in the chamber for each temperature use.

The collected experimental burning rate data have to be smoothed or fitted. This fitting should be with a minimal disturbance of the natural shape of the burning rate curve. Over the small ranges of pressure, a power law fit in equation (1) may be adequate [6].

$$
v=B p^{n}
$$

where:

$v$ burning rate,

$p$ pressure in the chamber,

$B$ const. depending on grain temperature and

$n$ pressure exponent.

This equation is functional when the change of pressure rate in the chamber is small enough and when the combustion pressure is approximately constant over the entire combustion surface.

Some additives could be added to the propellants in order to modify the burning rate and to maintain the burning rate and temperature sensitivity within acceptable parameters [7,8]. $\mathrm{ZrC}, \mathrm{Al}, \mathrm{TiO}_{2}$ and $\mathrm{Sb}_{2} \mathrm{O}_{3}$ are used for that purpose because of their ability to affect the CSP combustion characteristics: those compounds increase the melted binder viscosity of solid propellant, thereby preventing it to stir with the fine AP. This process enables proper burning at low and high pressures due to the loss of bad burning region in the pressure range [7]. It is important to emphasize that the changing of initial propellant's temperature, never modifies the contained chemical energy, but modifies the rate of chemical reactions during propellant combustion [9]. Since almost all missile systems are used in a wide temperature range, it is necessary that solid propellants have the temperature coefficient of the burning rate as small as possible.

Zirconium carbide $(\mathrm{ZrC})$ is an extremely hard refractory metallic powder with cubic crystal structure. Strong covalent $\mathrm{Zr}-\mathrm{C}$ bond gives this material a very high melting point $\left(3532^{\circ} \mathrm{C}\right) . \mathrm{ZrC}$ powder is shown in Fig. 1 .

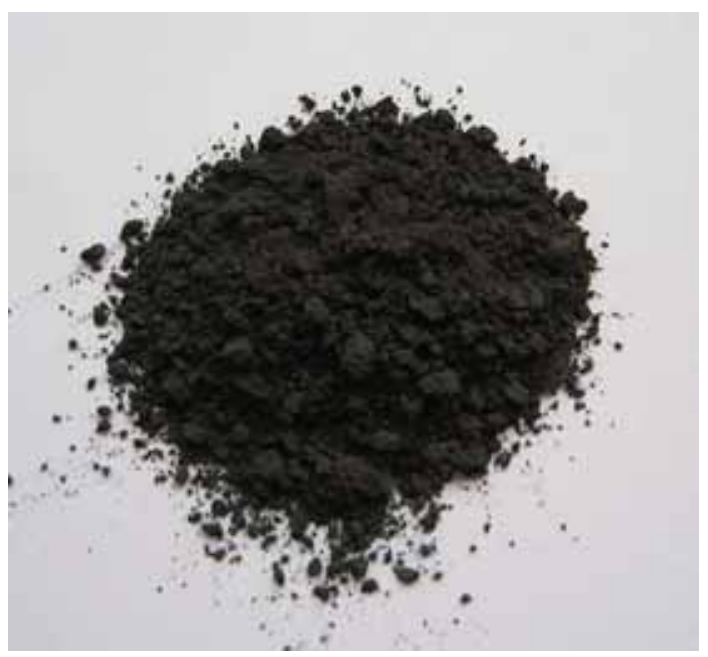

Figure 1. Zirconium carbide powder

Titanium dioxide, $\left(\mathrm{TiO}_{2}\right)$ or titania, has the melting point at $1843^{\circ} \mathrm{C}$. It may be found in nature as three minerals and as two high pressure forms, a monoclinic and an orthorhombic. Titania powder is given in Fig.2.

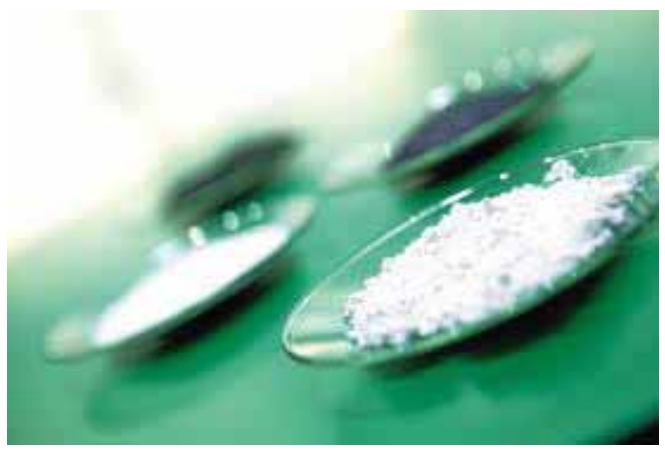

Figure 2. Titania powder

Antimony trioxide is the inorganic, amphoteric compound, with a melting point at $656^{\circ} \mathrm{C}$. Its structure depends on the temperature. Dimeric $\mathrm{Sb}_{4} \mathrm{O}_{6}$ is the gas at $1560^{\circ} \mathrm{C}$. Antimony trioxide powder is shown in Fig.3.

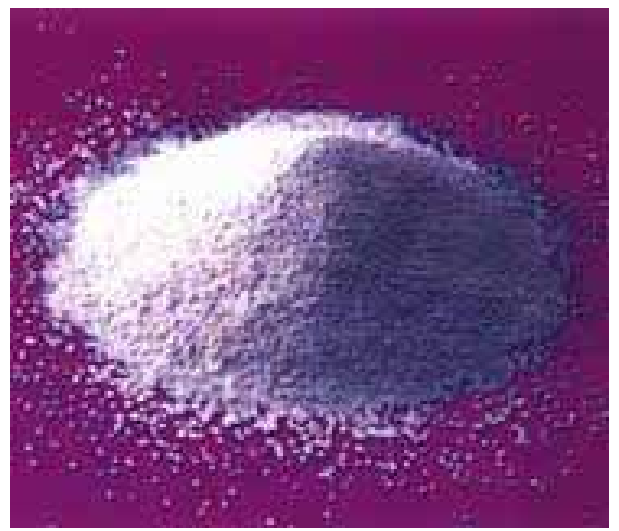

Figure 3. Antimony trioxide powder

Aluminium is a silvery white, soft metal with a melting point at $660^{\circ} \mathrm{C}$. This metal is so chemically reactive that native specimens are rare and limited to extremely reducing environments. It is remarkable for the metal's low density and for its ability to resist corrosion due to the phenomenon of passivation with aluminium (III) oxide $\mathrm{Al}_{2} \mathrm{O}_{3}$. Aluminium is a universal reductant for CSP, added in the form of the 
spherical particles with diameter sizes from several up to ten of microns; stirred well with the oxidizer and thus contributes to increase the total energy amount of the active components; the oxidant, which is almost always hygroscopic, is covered and protected with a thin layer of the aluminium particles, and thus allows manipulation with the uncured propellant. [9]. Al powder is shown in Fig.4.

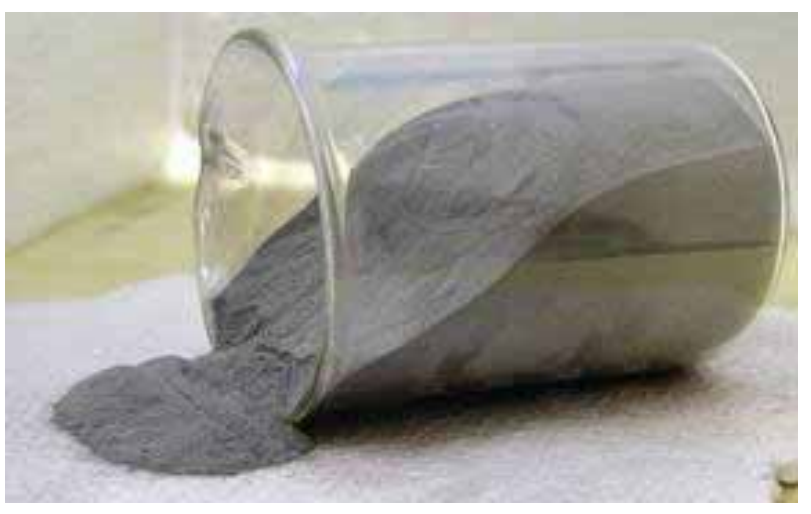

Figure 4. Aluminium powder

The effects of all mentioned additives have been compared in this work $[1,2,10]$.

\section{Experimental part}

The three groups of compositions with a different AP fractions combination have been prepared for this research:

Group 3: bimodal CSP (AP - $200 \mu \mathrm{m}, 80 \mu \mathrm{m})$;

Group 4: trimodal CSP (AP - $200 \mu \mathrm{m}, 80 \mu \mathrm{m}, 10 \mu \mathrm{m})$;

Group 5: bimodal CSP (AP - $200 \mu \mathrm{m}, 10 \mu \mathrm{m})$.

The compositions including $\mathrm{ZrC}$ (labelled as $\mathrm{Z}$ ), titania (T) and antimony trioxide (»S«) are made in each group, but one with $\mathrm{Al}(3 \mathrm{~A})$ and one without any stabilizers (3P) only in the group 3. The CSP binder compositions are based on hydroxylterminated polybutadiene (HTPB) and isophoronediisocyanate (IPDI) as a curing agent, with addition of other standard components such as plasticizer, bonding agent and antioxidant.

All ingredients have been homogenized at $50^{\circ} \mathrm{C}$ in the laboratory vertical planetary mixer. Afterwards, the propellant is cast in the blocks (for mechanical and physico-chemical tests) and in experimental motors for the static tests.

All the specimens are cured at the elevated temperature. The uncured propellant is used for the viscosity determination.

Static tests are performed for all of the mentioned batches (11) at two testing temperatures.

All the formulations are shown in Tables 1, 2 and 3.

Table 1. Bimodal CSP with 200 and $80 \mu \mathrm{m}$ AP

\begin{tabular}{|c|c|c|c|c|c|}
\hline No & $\begin{array}{c}200 \mu \mathrm{m}, \\
(\%)\end{array}$ & $\begin{array}{c}80 \mu \mathrm{m}, \\
(\%)\end{array}$ & $\begin{array}{c}\text { Add, } \\
(\%)\end{array}$ & $\begin{array}{l}\mathrm{AP}_{\text {tot. }} \\
(\%)\end{array}$ & $\begin{array}{c}\text { Total solid phase, } \\
(\%)\end{array}$ \\
\hline $3 \mathrm{P}$ & 60.80 & 15.20 & - & 76.0 & 76.0 \\
\hline $3 \mathrm{~A}$ & \multirow{3}{*}{62.40} & \multirow{3}{*}{15.60} & 6.0 & \multirow{3}{*}{78.0} & 84.0 \\
\hline $3 Z$ & & & 0.8 & & 78.8 \\
\hline $3 \mathrm{~T}$ & & & 1.0 & & 79.0 \\
\hline $3 \mathrm{~S}$ & 60.24 & 15.06 & 0.7 & 75.3 & 74.0 \\
\hline
\end{tabular}

Coarse to fine AP fraction ratio in Table 1 is $80 / 20$, known as the best fraction combination of $200 / 80 \mu \mathrm{m}$. Total AP content for CSP with antimony oxide (3S) is lower than the other two, because of its effect on the increase in viscosity values, especially in the presence of $0.5 \% \mathrm{Fe}_{2} \mathrm{O}_{3}$, (with * in Table 3) [11].
Table 2. Trimodal CSP with 200, 80 and $10 \mu \mathrm{m}$ AP

\begin{tabular}{|c|c|c|c|c|c|c|}
\hline No & $\begin{array}{c}200 \mu \mathrm{m}, \\
(\%)\end{array}$ & $\begin{array}{c}80 \mu \mathrm{m}, \\
(\%)\end{array}$ & $10 \mu \mathrm{m},(\%)$ & $\begin{array}{l}\text { Add, } \\
(\%)\end{array}$ & $\begin{array}{c}\mathrm{AP}_{\text {tot. }}, \\
(\%)\end{array}$ & $\begin{array}{l}\text { Total solid } \\
\text { phase, }(\%)\end{array}$ \\
\hline $4 Z$ & \multirow{3}{*}{22.5} & \multirow{3}{*}{34.3} & \multirow{3}{*}{21.5} & 0.5 & \multirow{3}{*}{78.3} & 78.8 \\
\hline $4 \mathrm{~T}$ & & & & 0.8 & & 79.1 \\
\hline $4 \mathrm{~S}$ & & & & 0.6 & & 78.9 \\
\hline
\end{tabular}

Table 3. Bimodal CSP with 200 and $10 \mu \mathrm{m} \mathrm{AP}$

\begin{tabular}{|c|c|c|c|c|c|}
\hline No & $\begin{array}{c}200 \mu \mathrm{m}, \\
(\%)\end{array}$ & $\begin{array}{c}10 \mu \mathrm{m}, \\
(\%)\end{array}$ & $\begin{array}{c}\text { Add, } \\
(\%)\end{array}$ & $\begin{array}{c}\mathrm{AP}_{\text {tot., }} \\
(\%)\end{array}$ & $\begin{array}{l}\text { Total solid } \\
\text { phase, }(\%)\end{array}$ \\
\hline $5 Z$ & \multirow{3}{*}{55.0} & \multirow{3}{*}{24.0} & 0.5 & \multirow{3}{*}{79.0} & $80.0 *$ \\
\hline $5 \mathrm{~T}$ & & & 0.7 & & $80.2 *$ \\
\hline $5 \mathrm{~S}$ & & & 0.5 & & 79.5 \\
\hline
\end{tabular}

Coarse to fine AP fraction ratio in Table 3 is 70/30, as good for combination of $200 \mu \mathrm{m}$ and $10 \mu \mathrm{m}$ powders.

\section{Results of examinations}

The viscosity changes during the curing time (measured every 15 minutes) have been determined with a Brookfield viscometer, HBT type, at $(50 \pm 2)^{\circ} \mathrm{C}$. The results are shown in Table 4, and the graphic review in Fig.5, for better visual comparison of all measuring values.

Table 4. Viscosity changes during the curing time

\begin{tabular}{|c||c|c|c|c|c|c|}
\hline \multirow{2}{*}{ No } & \multicolumn{6}{|c|}{ Viscosity (Pa s) vs. time (min) } \\
\cline { 2 - 7 } & 15 & 30 & 45 & 60 & 75 & 90 \\
\hline \hline $3 Z$ & 194 & 251 & 286 & 346 & 430 & 482 \\
\hline $3 \mathrm{~T}$ & 248 & 233.6 & 243.2 & 261.8 & 284.8 & 369.6 \\
\hline $3 \mathrm{~S}$ & 107.2 & 152 & 193.6 & 280 & 387.2 & 456 \\
\hline $4 \mathrm{Z}$ & 69 & 102 & 120 & 138 & 173 & 201 \\
\hline $4 \mathrm{~T}$ & 64 & 72 & 80 & 91.2 & 104 & 120 \\
\hline $4 \mathrm{~S}$ & 48.6 & 61.4 & 70.4 & 79.4 & 86.4 & 94 \\
\hline $5 Z$ & 75 & 102 & 128 & 136 & 154 & 168 \\
\hline $5 \mathrm{~T}$ & 80 & 104 & 116.8 & 136 & 148.8 & 169.6 \\
\hline $5 \mathrm{~S}$ & 48 & 60.8 & 76.8 & 91.2 & 104 & 111 \\
\hline \hline
\end{tabular}

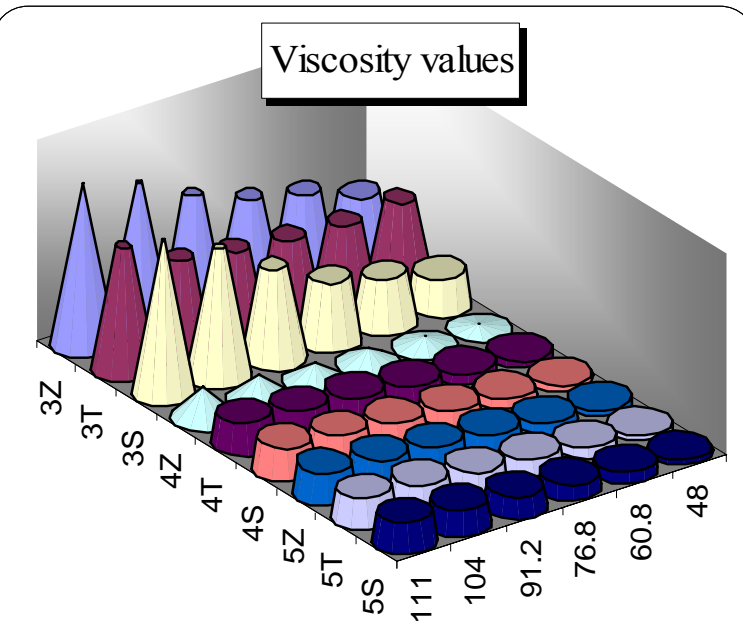

Figure 5. Viscosity values vs. curing time for nine examined propellant formulations

The mechanical characteristics are determined by the uniaxial tensile test at $(20 \pm 2)^{\circ} \mathrm{C}$ and a crosshead speed of $50 \mathrm{~mm} / \mathrm{min}$ at the INSTRON 1122 universal tensile tester. The graphic review of the tensile stress $\left(\mathrm{daN} \cdot \mathrm{cm}^{-2}\right)$ values are shown in Fig.6 and the two other in Fig.7: modulus of 
elasticity and strain at the maximum load values (the ordinate values are common for both characteristics).

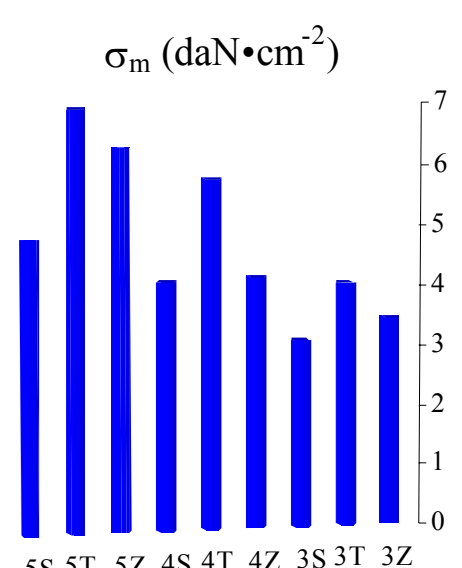

Figure 6. Tensile stress values for nine examined propellant formulations

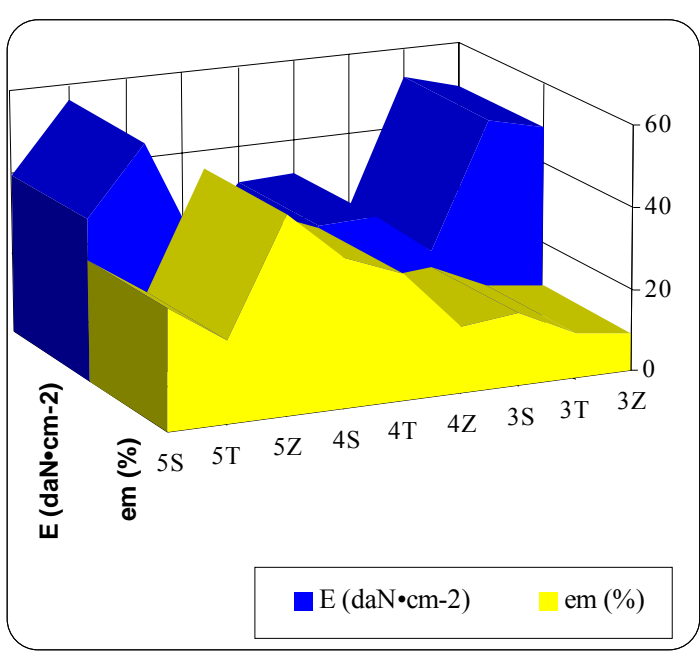

Figure 7. Modulus of elasticity and strain at the maximum load values for nine examined propellant formulations

The density values of the propellant specimens were measured by the Mohr balance and heat capacity by an IKACalorimeter C 2000. These results are shown in Fig.8.

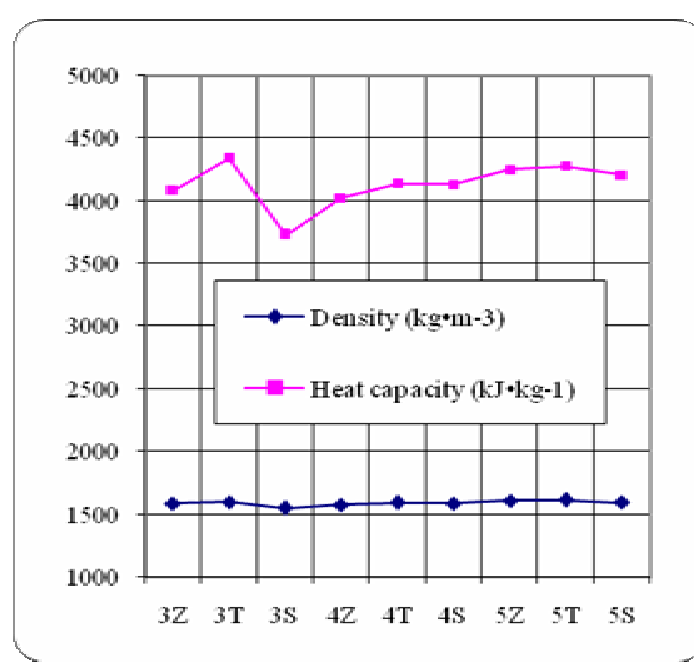

Figure 8. Heat capacity and density values for nine examined propellant formulations

Cast experimental two-inch-motors have been tested at a fire station at two temperatures and examination results of the burning parameters at $50^{\circ} \mathrm{C}$ and $-40^{\circ} \mathrm{C}$ are given in Tables 5 and 6: burning rate values at 70 bar $\left(v_{70}\right)$ and pressure exponents $(n)$.

Table 5. Burning rate law parameters at $50^{\circ} \mathrm{C}$

\begin{tabular}{|c|c|c||}
\hline \hline No & $v_{70}(\mathrm{~mm} / \mathrm{s})$ & $n$ \\
\hline \hline $3 \mathrm{P}$ & 6.49 & 0.1546 \\
\hline $3 \mathrm{~A}$ & 9.71 & 0.3461 \\
\hline $3 \mathrm{Z}$ & 8.48 & 0.5013 \\
\hline $3 \mathrm{~T}$ & 7.16 & 0.2300 \\
\hline $3 \mathrm{~S}$ & 5.54 & 0.1150 \\
\hline $4 \mathrm{Z}$ & 8.30 & 0.4238 \\
\hline $4 \mathrm{~T}$ & 8.29 & 0.3745 \\
\hline $4 \mathrm{~S}$ & 8.82 & 0.3991 \\
\hline $5 \mathrm{Z}$ & 11.70 & 0.4242 \\
\hline $5 \mathrm{~T}$ & 11.27 & 0.3956 \\
\hline $5 \mathrm{~S}$ & 7.32 & 0.2583 \\
\hline
\end{tabular}

Table 6. Burning rate law parameters at $-40^{\circ} \mathrm{C}$

\begin{tabular}{|c|c|c||}
\hline No & $\mathrm{V}_{70}(\mathrm{~mm} / \mathrm{s})$ & $\mathrm{n}$ \\
\hline \hline $3 \mathrm{P}$ & 5.39 & 0.2383 \\
\hline $3 \mathrm{~A}$ & 8.70 & 0.4458 \\
\hline $3 \mathrm{Z}$ & 7.23 & 0.4050 \\
\hline $3 \mathrm{~T}$ & 6.39 & 0.2037 \\
\hline $3 \mathrm{~S}$ & 4.65 & 0.0888 \\
\hline $4 \mathrm{Z}$ & 6.91 & 0.3085 \\
\hline $4 \mathrm{~T}$ & 7.31 & 0.3714 \\
\hline $4 \mathrm{~S}$ & 7.55 & 0.4121 \\
\hline $5 \mathrm{Z}$ & 10.39 & 0.4623 \\
\hline $5 \mathrm{~T}$ & 10.08 & 0.3368 \\
\hline $5 \mathrm{~S}$ & 6.15 & 0.2224 \\
\hline
\end{tabular}

Temperature sensitivities are determined by the burning rates at a chosen pressure and two testing temperatures.

$$
\sigma_{p}=\frac{\ln \left(v_{2} / v_{1}\right)_{p}}{T_{2}-T_{1}}
$$

$\sigma_{p} \quad$ temperature sensitivity at the pressure $p,\left({ }^{\circ} \mathrm{C}^{-1}\right)$,

$v_{2} \quad$ burning rate at the pressure $» \mathrm{p} \ll$ and temperature $T_{2}$ $(\mathrm{mm} / \mathrm{s})$;

$v_{1}$ burning rate at the pressure $» \mathrm{p} \ll$ and temperature $\mathrm{T}_{1}(\mathrm{~mm} / \mathrm{s}) ; \mathrm{T}_{2}>\mathrm{T}_{1}$, and

$p$ working pressure value in the motor chamber corresponding to the burning rates $v_{1}$ and $v_{2}$, (bar).

The values $\sigma_{p}$ for all batches are calculated from the equation (2), multiplied by 100 and given in Table 7 as $\sigma_{p}$ at 70 bar $\left(\% /{ }^{\circ} \mathrm{C}\right)$.

Table 7. Calculated values of temperature sensitivity

\begin{tabular}{||c|c||c|c||}
\hline No & $\sigma_{70}\left(\% /{ }^{\circ} \mathrm{C}\right)$ & No & $\sigma_{70}\left(\% /{ }^{\circ} \mathrm{C}\right)$ \\
\hline \hline $3 \mathrm{P}$ & 0.2063 & $4 \mathrm{~T}$ & 0.1401 \\
\hline $3 \mathrm{~A}$ & 0.1210 & $4 \mathrm{~S}$ & 0.1731 \\
\hline $3 \mathrm{Z}$ & 0.1763 & $5 \mathrm{Z}$ & 0.1320 \\
\hline $3 \mathrm{~T}$ & 0.1257 & $5 \mathrm{~T}$ & 0.1240 \\
\hline $3 \mathrm{~S}$ & 0.1948 & $5 \mathrm{~S}$ & 0.1928 \\
\hline $4 \mathrm{Z}$ & 0.2034 & & \\
\hline
\end{tabular}

\section{Discussion}

As it is seen, the 200/80 fraction combination in group 3 gives the higher viscosity values: adding one third finest 10 microns fraction decreases this value two times for group 4, but the best viscosity values were obtained for 200/10 fraction structure for group 5 . 
Generally, the tensile stress value increases by reducing the particle size of AP, so the maximum values were obtained for group 5 and in the formulations including three or more different fractions.

Density and heat capacity values are corresponding to their total AP and solid phase. These formulations do not belong to those of a high level of energy.

Burning rate laws at two temperatures will be graphically presented for the sake of a more convenient consideration and comparison of the compositions. Firstly, it may be seen for group 3 at $50^{\circ} \mathrm{C}$ and $-40^{\circ} \mathrm{C}$ in Figures 9 and 10 , respectively.

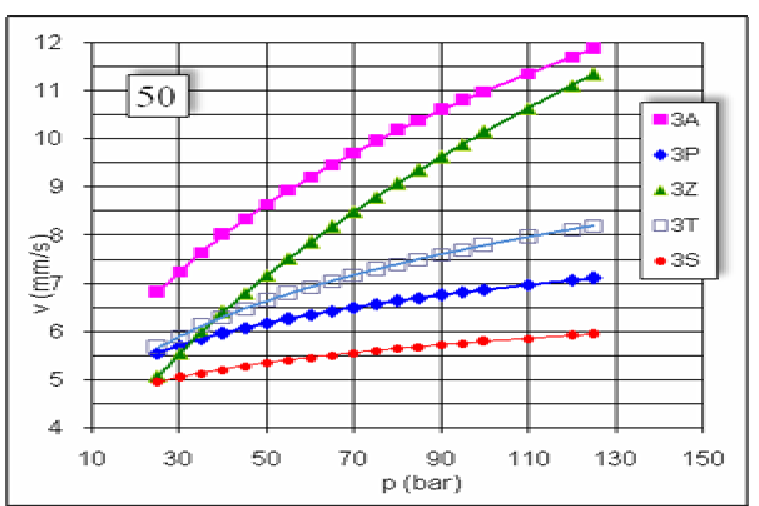

Figure 9. Burning rate laws for group 3 at $50{ }^{\circ} \mathrm{C}$

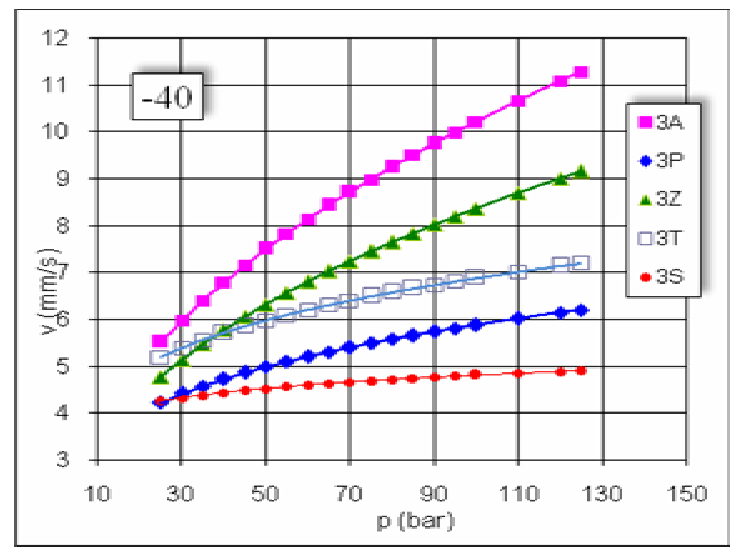

Figure 10. Burning rate laws for group 3 at $-40{ }^{\circ} \mathrm{C}$

As can be seen as an example in Fig.11 for the 3P composition without additives, by fitting dependence with the line through a plot, the obtained mathematical model defines its trend change in $\left(\% /{ }^{\circ} \mathrm{C}\right)$ as a function of pressures.

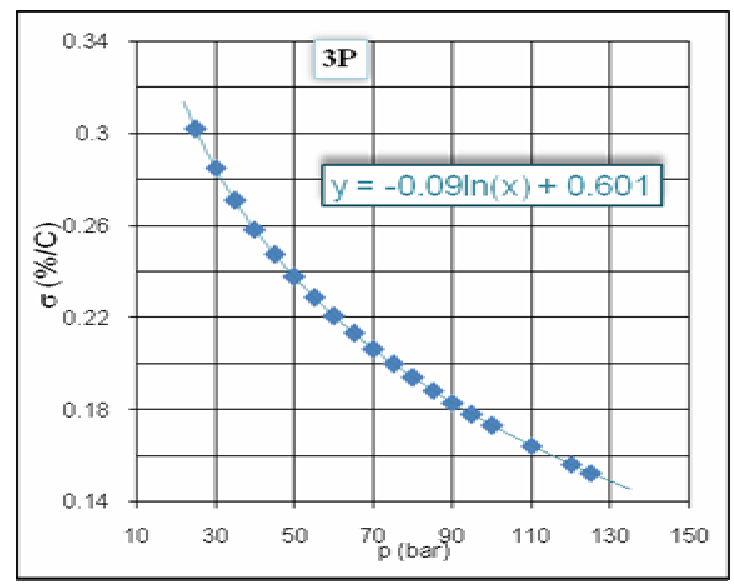

Figure 11. Dependence $\sigma=f(p)$ of the 3P composition
By calculating the values from the burning rate laws of four others from group 3 at the two temperatures, as $3 \mathrm{~A}, 3 \mathrm{Z}$, $3 \mathrm{~T}$ and $3 \mathrm{~S}$, the change of temperature sensitivity with pressure can be seen in the summarized data diagram in Fig. 12.

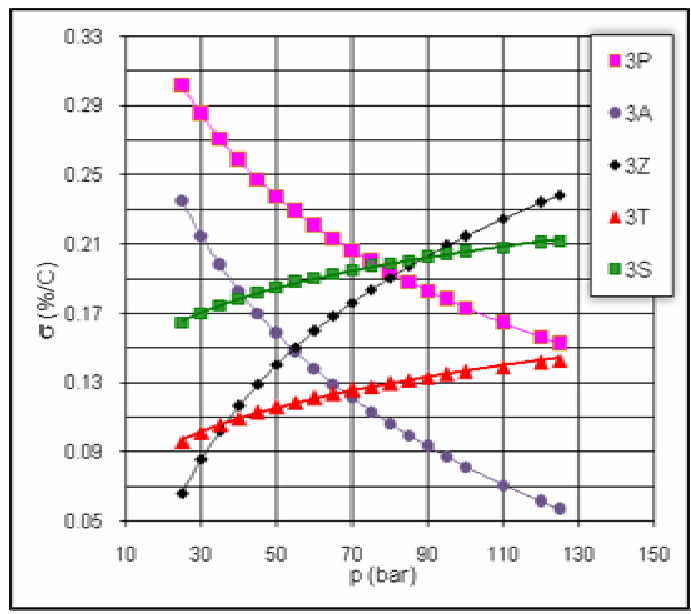

Figure 12. Dependence $\sigma=f(p)$ for bimodal group 3

Burning rate laws, from the Table 5 and 6 , obtained from the tests at the two temperatures of the next two groups (4 and 5), for trimodal and bimodal AP fraction compositions from the Table 2 and Table 3 are given in Figures 13 and 14.

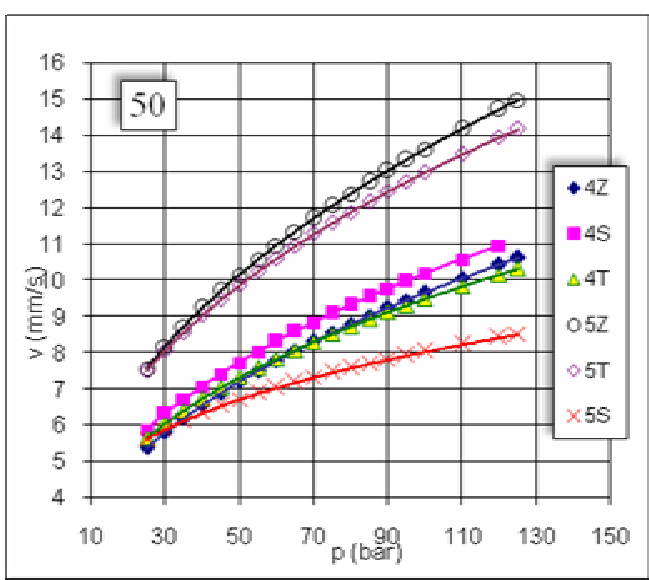

Figure 13. Burning rate laws for groups 4 and 5 at $50^{\circ} \mathrm{C}$

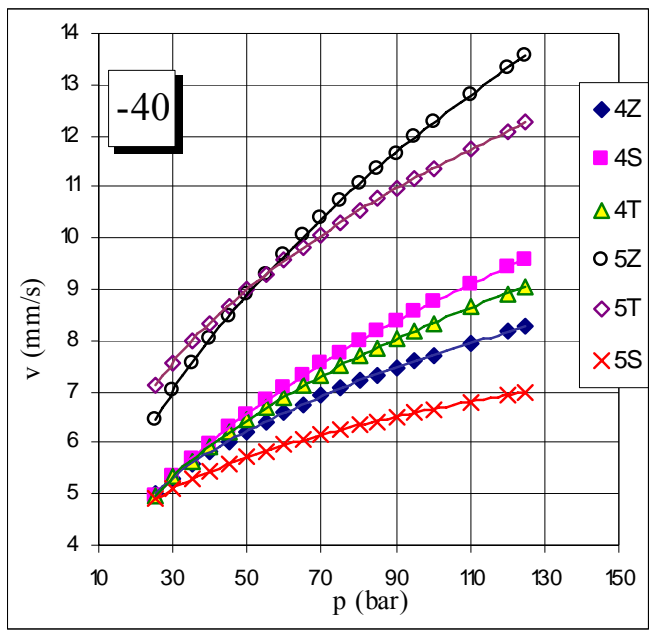

Figure 14. Burning rate laws for groups 4 and 5 at $-40^{\circ} \mathrm{C}$

So, the change of the temperature sensitivity values with the pressure range from equation (2) and results from Tables 5 
and 6 at the two temperatures for batches $4 \mathrm{Z}, 4 \mathrm{~T}$ and $4 \mathrm{~S}$, $(200 / 80 / 10 \mu \mathrm{m})$ are given in Fig.15.

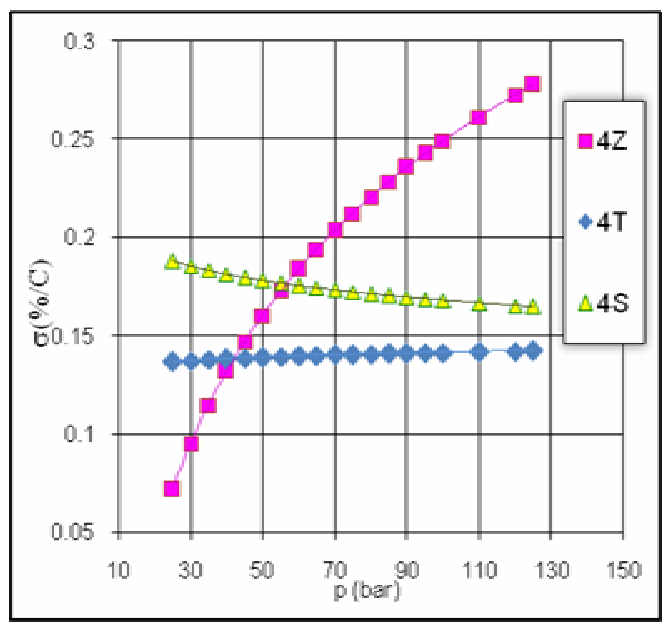

Figure 15. Dependence $\sigma=f(p)$ for trimodal group 4

Finally, for the last group of bimodal compositions (200/10 $\mu \mathrm{m}$ AP fractions), labeled as $5 \mathrm{Z}, 5 \mathrm{~T}$ and $5 \mathrm{~S}$, from the data from Table 5 and Table 6 , the calculated temperature sensitivities with the pressure were obtained.

The collection of these diagrams for group 5 is seen in Fig.16.

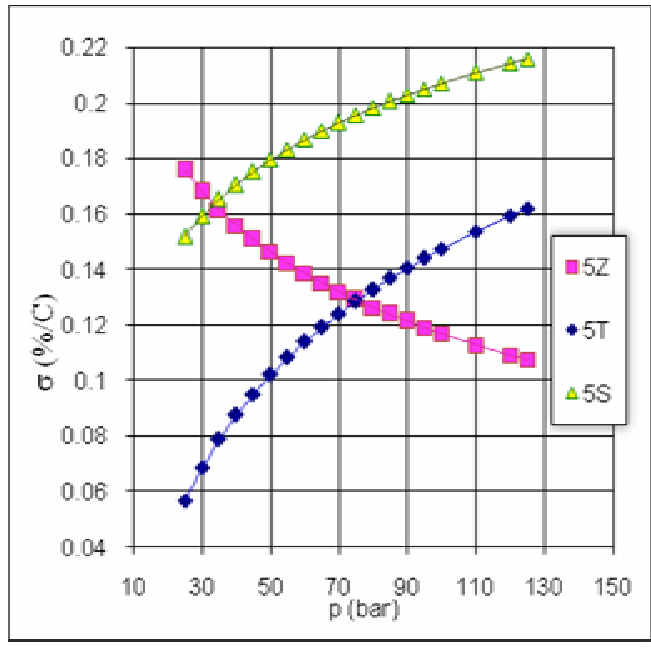

Figure 16. Dependence $\sigma=f(p)$ for bimodal group 5

Dependencies represented in Figures 12,15,16 may be mathematically fitted by the means of the function as follows:

$$
y=A \ln (x)+B
$$

as can be noticed in Fig.11. Values of coefficients A and B for all the combination are shown in Table 8 . If these functions are approximated by a straight-line equation, the value $A$ will be the slope of that line (the rate of rise and fall of the values) and $B-$ an intercept where the line crosses the $Y$-axis - and it serves as a prediction of the level of values.

From No 3 batches (200/80 $\mu \mathrm{m}$ AP), Figures 9 and 10, it is noticed that $3 \mathrm{~A}$ and $3 \mathrm{Z}$ have the highest pressure exponent and increase in the burning rate at 90 bar and more as opposed to the three other. But, only $3 \mathrm{~A}, 3 \mathrm{Z}$ and $3 \mathrm{~T}$ have the same total AP content and they can be compared: the composition including titania has the lowest rates and that with aluminium - the highest.

From Fig. 12 it is obvious that the opposite curve trend for $3 \mathrm{Z}, 3 \mathrm{~T}$ and $3 \mathrm{~S}$ corresponds to $\mathrm{3P}$ and $3 \mathrm{~A}$ where, by increasing the pressure, $\sigma$ decreases $(\mathrm{A}<0$, Table 8$)$. It means that the differences between the burning rates at $50^{\circ} \mathrm{C}$ and $-40^{\circ} \mathrm{C}$ are significantly dropping (3A) at higher pressures (>120 bar). Nevertheless, a great change of these rates' ratio occurs at some lower pressures, $(<80 \mathrm{bar})$. On the other hand, the trend of curves for $3 \mathrm{Z}, 3 \mathrm{~T}$ and $3 \mathrm{~S}$ compositions is in opposition to $3 \mathrm{~A}$ and $3 \mathrm{P}$, and those three show lower temperature sensitivity in the whole range of pressure and milder change (particularly for $3 \mathrm{~T}$ and $3 \mathrm{~S}$ ), while $3 \mathrm{Z}$ does not show the desirable trend. However, $\sigma$ is under $0,2 \% /{ }^{\circ} \mathrm{C}$, in an entire working range, which means for the values above 70 bar.

Table 8: Coefficients for equation $\mathrm{y}=\mathrm{A} \cdot \ln (\mathrm{x})+\mathrm{B}$

\begin{tabular}{||c|c|c||}
\hline Batch & A & B \\
\hline \hline $3 \mathrm{P}$ & -0.090 & 0.601 \\
\hline $3 \mathrm{~A}$ & -0.111 & 0.592 \\
\hline $3 \mathrm{Z}$ & 0.107 & -0.278 \\
\hline $3 \mathrm{~T}$ & 0.029 & 0.001 \\
\hline $3 \mathrm{~S}$ & 0.029 & 0.071 \\
\hline $4 \mathrm{Z}$ & 0.128 & -0.340 \\
\hline $4 \mathrm{~T}$ & 0.003 & 0.125 \\
\hline $4 \mathrm{~S}$ & -0.010 & 0.234 \\
\hline $5 \mathrm{Z}$ & -0.040 & 0.311 \\
\hline $5 \mathrm{~T}$ & 0.065 & -0.153 \\
\hline $5 \mathrm{~S}$ & 0.039 & 0.023 \\
\hline
\end{tabular}

From No 4 batches $(200 / 80 / 10 \mu \mathrm{m} \mathrm{AP})$ and from their burning rates, Fig. 13 and 14, it is seen that all of them have similar $\left(-40^{\circ} \mathrm{C}\right)$ or identical $\left(50^{\circ} \mathrm{C}\right)$ burning rate laws with the exponent values at the upper limit of the acceptance.

From Fig. 15 it is evident that the different character of $\sigma=$ $f(p)$ exists for $4 \mathrm{Z}$ and the two other compositions. This can be evaluated from Table 8 and by observing the values of gradient $A$. Temperature sensitivity of trimodal formulation $4 \mathrm{Z}$ is very undesirable because of the fact that this characteristic has rather high values in the whole optimal pressure range. $3 \mathrm{Z}$ and $4 \mathrm{Z}$ can be well compared because of the same total amount of solid content, but different fraction content. $4 \mathrm{~T}$ and $4 \mathrm{~S}$ are more prosperous, because their $\sigma$ is below 0,15 and 0,19 respectively. These are trimodal CSP with very sensible combustion stability and higher-pressure exponent comparing to the bimodal CSP with the same total solid content and the same additive.

From No 5 batches (200/10 $\mu \mathrm{m}$ AP), and their burning rate law parameters, Figures 13 and 14, it was not possible to cast the same samples of $5 \mathrm{~S}$ with $\mathrm{Fe}_{2} \mathrm{O}_{3}$, because of its adverse "pot life", so its burning rate parameters look very "controlled". The same parameters for the two other batches discourse somewhat better combustion properties of titania additive with the expectable levels of rates.

The temperature sensitivity dependencies at the same group (5) are presented in Fig.16. The run of CSP with zirconium carbide is reverse from the others in groups 3 and 4 , but also in the group 5: by increasing the pressure, $\sigma$ is dropping $(A<0$, Table 8$)$; the difference of burning rates at $50^{\circ} \mathrm{C}$ and $-40^{\circ} \mathrm{C}$ is dropping; CSP incorporated with antimony - and titanium oxide shows the increase in $\sigma$, but not over $0,16 \% /{ }^{\circ} \mathrm{C} .5 \mathrm{~S}$ has the highest ordinate values in the whole range. It is interesting that $5 \mathrm{~S}$ with a greater total solid and $\mathrm{AP}$ content has lower rates than $4 \mathrm{~S}$ for both temperatures.

\section{Conclusion}

The examination from this paper corresponds to the comparison of the developed composite solid propellants 
based on the hydroxyl-terminated polybutadiene prepolymer and ammonium-perchlorate as the oxidizer. The eleven compositions are divided into three groups of AP fractions: I - bimodal AP fractions (200 $\mu \mathrm{m}$ i $80 \mu \mathrm{m}$ in ratio 80/20) including four combustion stabilizers: $\mathrm{ZrC}, \mathrm{TiO}_{2}, \mathrm{Sb}_{2} \mathrm{O}_{3}$ and $\mathrm{Al}$, and one without any additive;

II - trimodal AP fractions $(200 \mu \mathrm{m}, 80 \mu \mathrm{m}$ and $10 \mu \mathrm{m})$ including $\mathrm{ZrC}, \mathrm{TiO}_{2}, \mathrm{Sb}_{2} \mathrm{O}_{3}$ and

III - bimodal AP fractions $(200 \mu \mathrm{m}$ i $10 \mu \mathrm{m}$ in ratio 70/30) also with $\mathrm{ZrC}, \mathrm{TiO}_{2}, \mathrm{Sb}_{2} \mathrm{O}_{3}$.

The 200/80 fraction combination in group 3 gives the higher viscosity values: adding the third finest 10 microns fraction decreasing this value for two times for group 4, but the best viscosity values were obtained for 200/10 fraction structure for group 5, no more than $200 \mathrm{~Pa} \cdot \mathrm{s}$ in 90 minutes after adding of curing agents.

The tensile stress value increased by reducing the particle size of AP, so the maximum values were obtained for group 5 and in the formulations including three or more different fractions.

Density and heat capacity values corresponding to their total AP and solid phase. These formulations do not belong to those of a high energy level.

Examinations of the burning rate law parameters at $50^{\circ} \mathrm{C}$ and $-40^{\circ} \mathrm{C}$ of all batches have been done. Using them, the temperature sensitivity was determined at a chosen pressure and the change of temperature sensitivity with the pressure was plotted in order to compare the curves for all compositions.

$3 \mathrm{~A}$ and $3 \mathrm{Z}$ have the highest exponent and the burning rates, as opposed to the $3 \mathrm{~T}, 3 \mathrm{P}$ and $3 \mathrm{~S}$ with very desirable properties. The titania composition has the lowest rates, as it is expectable, and the one with aluminium - the highest. The curves for $3 \mathrm{Z}, 3 \mathrm{~T}$ and $3 \mathrm{~S}$ show the lower temperature sensitivity in the whole range and a milder change of $\sigma$, which is under $0,2 \% /{ }^{\circ} \mathrm{C}$.

In No 4 batches, the range of burning rates is very narrow with the exponent values at the upper limit of the acceptance.

The character of $\sigma=f(p)$ for $4 \mathrm{Z}$ and the two others is different in observance of the values of gradient $A$. Temperature sensitivity of trimodal version $4 \mathrm{Z}$ is very undesirable because of rather high values in the whole pressure range. $4 \mathrm{~T}$ and $4 \mathrm{~S}$ are more favourable $(\sigma<0,15$ and 0,19 respectively).

For batches No 5 it was not possible to cast same samples of $5 \mathrm{~S}$ with $\mathrm{Fe}_{2} \mathrm{O}_{3}$, because of its adverse "pot life", and very acceptable burning rate parameters. There are somewhat better combustion properties of titania additive with the expectable levels of rates.
The curve trend of CSP with zirconium carbide (5Z) is diametrically reverse from the others with the same additive in groups 3 and 4, but also from the others in the same group 5. CSP with antimony - and titanium oxide shows the increase of $\sigma$, but not over $0,16 \% /{ }^{\circ} \mathrm{C}$. $5 \mathrm{~S}$ has the highest yaxes values in the whole range.

The choice of some types of a compound in the role of a combustion stabilizer depends on the requirements and desirable properties. Except the observed characteristics, many other can affect our consideration and decisions.

\section{Literature}

[1] RODIĆ,V., FIDANOVSKI,B.: Burning Stability of Composite Solid Propellants Including Zirconium Carbide, Scientific Technical Review, ISSN 1820-0206, Belgrade, SERBIA, 2013, Vol.63, No.3, pp.33-40.

[2] RODIĆ,V.: The effect of titanium (IV) oxide on burning stability of composite solid propellants, $4^{\text {th }}$ Internationa Scientific Conference on Defensive Technologies OTEH 2011, 6-7.October 2011., Military Technical Institute, Belgrade, SERBIA, ISBN 978-86-81123-50-8, pp. 354-360.

[3] WEIDONG,C., PIYUSH,T., VIGOR,Y.A.: Model of $A P / H T P B$ Composite Propellant Combustion in Rocket-motor Environments, Combust. Sci. and Tech., 180: 2143-2169, 2008.

[4] KIERAN,F.D.: Measurement of rocket performance variation with propellant mixture and preparation, Initial Thesis Report 2009, ACME, NSW@ADFA

[5] KISHORE,K., SRIDHARA,K.: Effect of Surface Microstructure on the Temperature Sensitivity of Burning Rate of Ammonium Perchlorate : Indian Institute of Science, Bangalore-560 012 - Defence Science Journal, April 1997, Vo1.47, No.2, pp. 177-184

[6] ATWOOD,A., BOGGS,I.T.L., CURRAN,P.O., PARR,T.P., HANSON-PARR, D.M.: Burning Rate of Solid Propellant Ingredients, Part 2: Determination of Burning Rate Temperature Sensitivity U.S. Naval Air Warfare Center, China Lake, California 93555 JouRNAL OF PROPULSION AND POWER, November-December 1999, Vol.15, No.6.

[7] KUM,M.I.: Composite propellants with bi-plateau burning behaviour, Weapons system division, DSTO-GD-0344, 2003.

[8] DAUME,E., SARBACH,J.: Incendiary Composition Containing $A$ Group IVB Metallic Fuel, US Patent 4,402,705, Sept. 6, 1983.

[9] ZEČEVIĆ,B.: Utjecaj promjenjivog polja visokog radijalnog ubrzanja na unutrašnju balistiku raketnih motora sa dvobaznim gorivom, doktorska disertacija, Univerzitet u Sarajevu, Bosna i Hercegovina, 1999.

[10] RODIĆ,V.: Effect of titanium (IV) oxide on composite solid propellant properties, Scientific Technical Review, ISSN 1820-0206, Belgrade, SERBIA, 2012, Vol.62, No.3-4, pp.21-27.

[11] PETRIĆ,M., RODIĆ,V.: The effect of additives on solid rocket propellant behavior, Scientific Technical Review, ISSN 1820-0206, Belgrade, SERBIA, 2004, Vol. LIV, No.3-4, pp.9-14.

\title{
Livena čvrsta raketna goriva sa različitim stabilizatorima sagorevanja
}

\begin{abstract}
U ovom radu je prikazan uticaj četiri različita jedinjenja, kao stabilizatora sagorevanja, na kompozitna raketna goriva na bazi AP/HTPB/IPDI. Osim toga, izrađeno je jedanaest sastava sa različitim udelom čvrste faze i kombinacijama bimodalnih $i$ tromodalnih frakcija čestica amonijum-perhlorata različitog odnosa za sve sastave. određeni su i poređeni parametri zakona brzine sagorevanja i temperaturske osetljivosti, vrednosti mehaničkih karakteristika testom jednoosnog zatezanja, promene vrednosti viskoziteta neumreženog goriva, kao i fizičko-hemijske i energetske vrednosti goriva.
\end{abstract}

Ključne reči: čvrsto raketno gorivo, kompozitno raketno gorivo, liveno gorivo, stabilnost sagorevanja, stabilizatori, aluminijum, cirkonijum karbid, titan oksid, antimon oksid, termička osetljivost, brzina sagorevanja. 


\title{
Литые твёрдые ракетные топлива с различными стабилизаторами горения
}

\begin{abstract}
В настоящей работе описывается влияние четырёх различных соединений, таких как стабилизаторы горения, на композитные ракетные топлива на основе АР/HTPB/IPDI. Кроме того, сделано одиннадцать составов с различными содержаниями твёрдых фаз и с комбинациями бимодальных и тримодальных фракций частиц перхлората аммония разных отношений. Для всех составов были определены и сравнены параметры закона скорости горения и температуры чувствительности, значения механических характеристик проверкой одноосого растяжения, изменения значений вязкости неполимеризованного топлива, а в том числе и физико-химические и энергетические ценности топлива.
\end{abstract}

Ключевые слова: твёрдое ракетное топливо, композитное ракетное топливо, литое топливо, стабильность горения, стабилизаторы, алюминий, карбидциркония, оксид титана, оксид сурьмы, тепловая чувствительность, скорость горения.

\section{Propergols solides de fonte avec les différents stabilisateurs de combustion}

\begin{abstract}
Dans ce papier on présente l'effet produit par quatre compositions différentes comme stabilisateurs de combustion sur les propergols composites à la base $\mathrm{AP} / \mathrm{HTPB} / \mathrm{IPDI}$. A part cela on a fait onze compositions avec différent contenu de phase solide et avec les combinaisons de fractions des particules d'ammonium perchlorate bimodales et tri modales de proportion variée. Pour toutes les compositions on a déterminé et comparé les paramètres de la loi de vitesse de combustion et les sensitivités thermiques, les valeurs des caractéristiques mécaniques, au moyen du test de tension maximale, les changements des valeurs de viscosité du propergol non durci ainsi que les valeurs physiques, chimiques et énergétique du propergol.
\end{abstract}

Mots clés: propergol solide, propergol composite, propergol de fonte, stabilité de combustion, stabilisateurs, aluminium, zirconium carbure, oxyde titane, oxyde antimoine, sensitivité thermique, vitesse de combustion. 